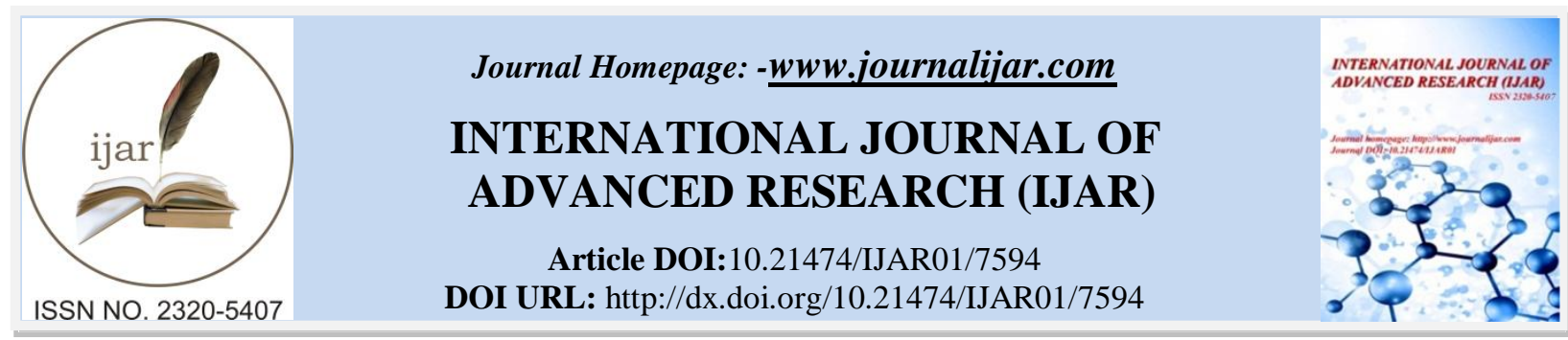

RESEARCH ARTICLE

\title{
NUMERICAL STUDY OF MIXED CONVECTION IN THEPHOTOVOLTAIC TROMB WALL WINDOW FOR PASSIVE COOLING IN BIOCLIMATIC BUILDINGS.
}

\author{
"Yawovi Nougbléga, Kokou N'wuitcha, Kodjo Kpode, Kossi Atchonouglo and Magolmééna Banna. \\ Laboratoire Sur l'Energie Solaire /Groupe Phénomène de Transfert et Energétique - Université de Lomé01 BP 1515 \\ Lomé 01-Togo.
}

\section{Manuscript Info}

Manuscript History

Received: 18 June 2018

Final Accepted: 20 July 2018

Published: August 2018

Keywords:-

Mixed convection, PVT romb wall window,solar chimney, passive cooling,

Thermal comfort.

\begin{abstract}
A numerical study is conducted to investigate mixedconvectionwith the Boussinesq approximation in the Photovoltaic Trombwall window for passive cooling in the building.The small sized solar chimney, specially having a variable absorberplate height heated from thefronttop solar PV cells plate with a constant flux is integrated at the south façade of the building. Then three different values respectively for absorber height, chimney width, and inlet opening size are considered for different combinations of the governing parameters namely, Reynolds number $(20<\operatorname{Re}<200)$ and the Grashof number $\left(10^{4}<\mathrm{Gr}<10^{6}\right)$. The results are presented in the form of streamline and isotherm plots, mass flow rate, outlet velocity,PV cells' electrical efficiency, the variation of local Nusselt number on the heated plates
\end{abstract}

Copy Right, IJAR, 2018,. All rights reserved.

\section{Introduction:-}

Ventilation is one of the important options in providing thermal comfort in buildings. A solar chimney is one of several available options for achieving natural ventilation in a building through solar induced air movement. A solar chimney can be constructed in one of the components of a building, in which one or more walls of a vertical chimney are made transparent by providing glazed wall(s) for allowing solar radiation to accumulate enough heat to induce the chimney effect. Solar energy heats up the air inside the chimney. As a result of the temperature difference in the air, a density gradient between the inside and outside of the chimney is obtained that in turn induces a naturalupwardairmovement. The solar chimney is similar to the Tromb wall concept. The distinct difference between them is that while the Tromb wall has a massive thermal wall that absorbs solar energy and recirculates warm air for passive heating of the building, the solar chimney does not have a massive wall. Rather, storage of heat in the wall behind the absorber is undesirable. The Tromb wall has been used for decades as an efficient solar heating method. There is a massive thermal wall and a clear glazing cover with an air duct in between. As the surface of the thermal wall is painted black, it is hard to meet the aesthetic requirement of buildings. PV cells integrated on the cover glazing of theTromb wall are more appealing. Hence (Sun, W. et al, 2011) in their study have proved that the PV Tromb wall converts solar radiation into electricity and heat simultaneously. In contrast to the application of the Tromb wall, the purpose of a solar chimney is to provide ventilation to the building during the day without recirculation of room air. The energy used for heating, cooling and air conditioning of buildings should be minimized with some design based precautions. Thus(Yilmaz et al., 2008) proposed that special systems like the Tromb wall system might be used to decrease energy consumption in buildings. (Zamora et al., 2009) indicated that theTromb wall system uses solar energy to heat, ventilate and provide thermal comfort in buildings. In fact (Aste et al., 2008) proved in their study that the PV/T collectors aim is to increase electrical efficiency of the PV 
cells by cooling the PV module surface. Hence the BIPV Tromb wall is a novel version in which glazing in the classic Tromb wall is replaced by a PV module.

In other words, the BIPV Tromb wall is a combination of these two systems used both for producing electricity and heat simultaneously for energy saving. In the BIPV Tromb wall, the cool air in the room enters the inter-space through the lower vent, absorbs the waste heat behind the PV panels, becomes hot and enters the room through the upper vent. (Chow et al., 2005) indicated that the absorption of PV heat results in an increase in PV efficiency as the PV panels function better when they are cool. Furthermore, (Hegazy et al., 2000)have proved that free air convective cooling is a simple and low cost method of keeping electrical efficiency at an acceptable level. It is an energy efficient system that is easy to apply on the south facing facades of both existing and new buildings. Nowadays, Bioclimatic Integrated Photovoltaic-Thermal (BIPV/T) systems have turned out to be an attractive technology. Either semi-transparent or opaque type photovoltaic modules can be used in BIPV/T systems. (Agrawal et al., 2010)showed that the semi-transparent type systems are integrated with the walls, roofs and windows of buildings using day lighting, while the opaque type systems and the semi-transparent type systems without lighting can be integrated with the walls and roofs of buildings.

(Cheng et al., 2009) developed a correlation between the optimal angle of the BIPV system and the latitude of the site of the system. The system is supposed to be integrated on thesouth oriented tilted roof at 20 different locations in the Northern Hemisphere. Therefore, it was concluded that to get maximum solar radiation in thenorthern hemisphere, the system should face south and the angle of the panel should be equal to the latitude of the terrain. Then (Sun et al., 2011) carried out experimental and numerical studies to investigate the performance of PV Tromb Walls with different south façade designs. They developed a dynamic numerical model to integrate the vented PV Tromb Walls with theindoor environment. Thus, they concluded that in the design ofa south façade integrated with PV Tromb Walls, the dynamic coupling among PV Tromb Walls, window and indoor air must be taken into account. Hence, (KundakciKoyunbaba et al., 2011)developed a two dimensional CFD model under transient conditions for the BIPV Tromb wall system. They validated the simulation model by comparing the simulation and the experimental results. (KundakciKoyunbaba et al., 2012) developed two-dimensional CFD models under transient conditions for single-glass, double-glass and a-Si semi-transparent PV modules integrated on the Tromb wall facades of a model test room. Then Semi-transparent PV modules may replace window glazing owing to the light transmission and electricity generation capability. The interaction between the BIPV window and the building involves PV electricity generation, thermal loads, lighting energyconsumption and visual comfort of the building. There are generally three forms of BIPV windows in current research: single pane, double-pane with enclosed air cavity, and ventilated double-pane with open air cavity. (Li et al., 2009)showed that visual discomfort; solar heat gain, lighting energy consumption and HVAC equipment size can be reduced by replacingthe south west-facing tinted glass windows with semi-transparent a-Si PV panels and applying lighting controls in a typical office building in Hong Kong. (Lu and Law, 2013) also pointed out that using semi-transparent c-Si BIPV windows may enhance building energy performance. They suggested the following optimal office orientations for annual electricity savings in the following order for Hong Kong: south-east, south, east, south-west and west. (Olivieri et al., 2014)concluded that for intermediate and large openings covering more than $33 \%$ of the façade area, BIPV windows account for 18$59 \%$ energy savings compared to glass when applied to a typical middle-size office building in Spain. (Miyazaki et al., 2005) showed that primary energy consumption of a buildingcan be reduced by installing this type of BIPV window and adopting lighting controls. They suggested optimal transmittances of the PV module in accordance with different window to wall ratios of the building. A low emissivity coating was further shown by (Han et al., 2010)to reduce radiative heat transfer and the U-value of this BIPV window configuration. Hence (Chae et al., 2014)showed that up to $30 \%$ of the annual HVAC energy consumption can be saved by installing double-pane semi-transparent BIPV windows as opposed to double-pane clear glass windows, in the low and medium latitude US cities. Semitransparent PVs with different optical properties were recommended for maximum utility cost savings for these cities. The experiments conducted by (He et al., 2011) indicated that the indoor heat gain of the ventilated doublepane BIPV window was reduced to less than half of that of the single pane BIPV window. The thermal comfort level of the work space was also improved due to the lower inner surface temperature of the ventilated double-pane BIPV window. (Chow et al., 2007a)showed that a PV transmittance of 0.45-0.55 in the ventilated BIPV window resulted in the greatest electricity saving when taking into account air-conditioning load, artificial light consumption and PV electrical generation. Annually the BIPV window can cut down air conditioning power consumption by $28 \%$ for a typical Hong Kong office, compared to the conventional single absorptive glass window; (Chow et al., 2009). The authors also stated that high efficiency thin-film solar cells could facilitate the uptake of PV double-pane windows. 
From a monetary point of view, (Ng and Mithraratne, 2014) showed that with government subsidies certain PV modules with high efficiencies are cheaper to install than conventional double-glazed windows.

However on the basis of litterature review, it appears that no work in surveyed papers was reported on mixed convection in the PV windows integrated on the facade of buildings. None of the surveyed papers however showed the interrelated influence of the thermal efficiency or the electrical efficiency of the solar PV cells in the ventilation process in the room. Thereafter, due to the practical importance of this problem in a wide variety of engineering applications of passive cooling, thermal comfort. Hence the subject needs further effort to improve our knowledge in this field. The aim of this study is to explore the possibility of using the small sized window openings as solar chimneys for passive cooling in buildings.

The object of the present paper is to study numerically a mixed convection problem in a small-sized solar chimney, specially having a variable absorber height(PV window) heated from the front top solar PV cells plate with a constant flux. In this analysis, the air flow enters the PVwindow through an inside opening size in the room andleaves from the outlet opening size. Then it is very important to know the air movement or temperature distribution inside the PV Tromb wall windowand the PV cells' electrical efficiency.

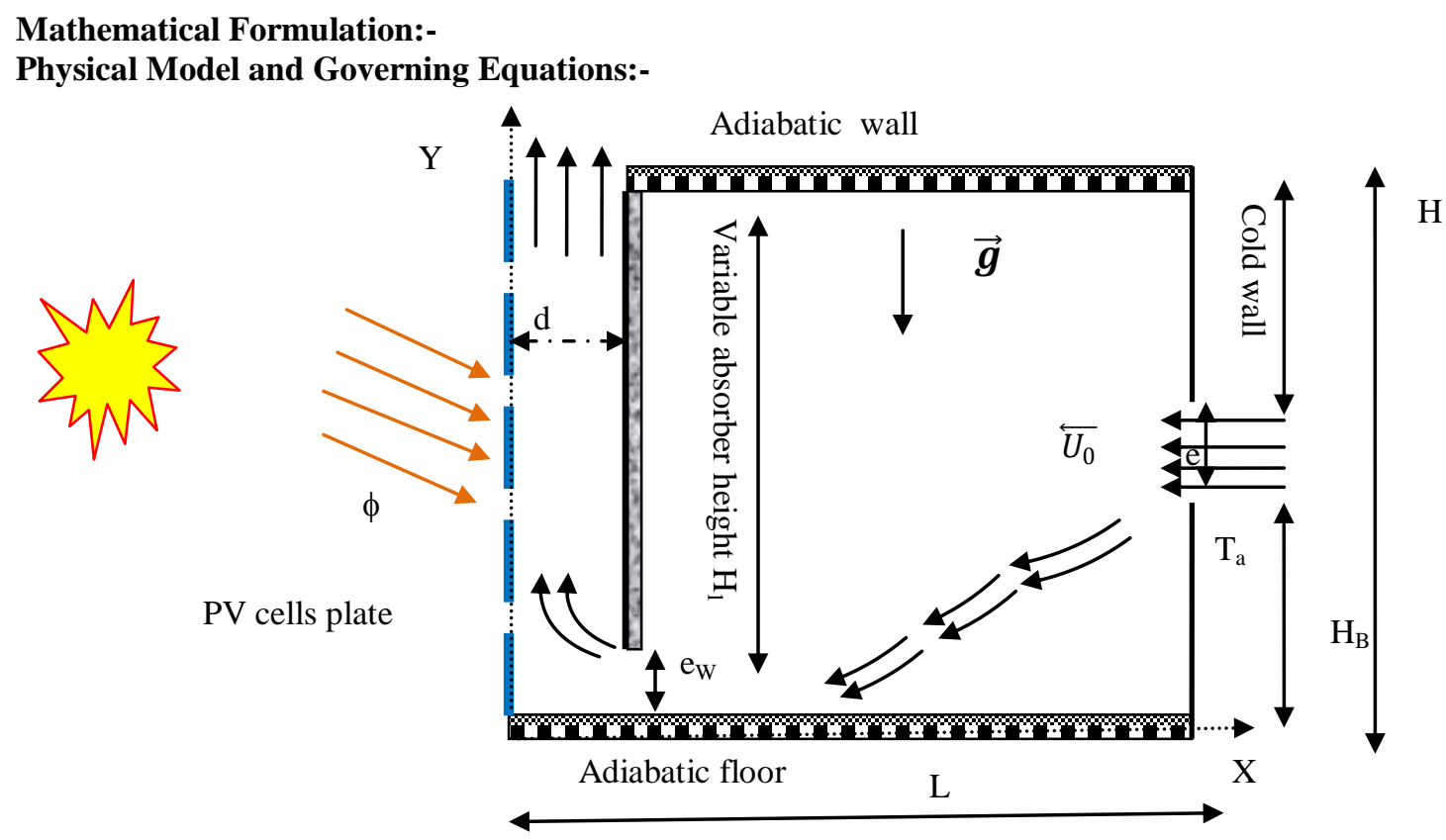

Fig.1:- Physical model

The geometrical configuration deals with a simple room with length Land height hmounted on the left side of the vertical parallel plates of the chimney. The chimney is designed as a solar collector with plate separation dand height h. The PV/T collector is composed of four elements: the front glass cover, the semi-transparent photovoltaic cells (PV), the air flow, the absorber plate. The collector acts as an exhaust fan by sucking room air and venting it out during sunshine hours. In the system, the PV panel absorbed the incident solar radiation and transfers heat to air in the gap by convection and radiation phenomena. The temperature of the absorber plate with variable height $\left(\mathrm{h}_{1}\right)$, rises and in turn, together with the PV module, heats up the air in the gap. The right side cold wall is maintained at the ambient temperature, the upper horizontal wall and the floor of the room are assumed perfectly insulated and adiabatic. The physical system is sketched in fig1.

The non dimensional set of the governing equations (continuity, momentum and energy equations) for a twodimensional, incompressible laminar flow are the following: 


$$
\begin{gathered}
\frac{\partial U}{\partial X}+\frac{\partial V}{\partial Y}=0 \\
\frac{\partial \omega}{\partial \tau}+U \frac{\partial \omega}{\partial X}+V \frac{\partial \omega}{\partial Y}=R i \frac{\partial \theta}{\partial X}+\frac{1}{R e}\left(\frac{\partial^{2} \omega}{\partial X^{2}}+\frac{\partial^{2} \omega}{\partial Y^{2}}\right) \\
\frac{\partial \theta}{\partial \tau}+U \frac{\partial \theta}{\partial X}+V \frac{\partial \theta}{\partial Y}=\frac{1}{R e P r}\left(\frac{\partial^{2} \theta}{\partial X^{2}}+\frac{\partial^{2} \theta}{\partial Y^{2}}\right)(3) \\
\omega=-\left(\frac{\partial^{2} \psi}{\partial X^{2}}+\frac{\partial^{2} \psi}{\partial Y^{2}}\right)
\end{gathered}
$$

The stream function and the vorticity are related to the velocity components by the following expressions:

$$
U=\frac{\partial \psi}{\partial Y} ; \quad V=-\frac{\partial \psi}{\partial X} \text { and } \omega=\left(\frac{\partial V}{\partial X}-\frac{\partial U}{\partial Y}\right)(5)
$$

Where the scales are defined: $X=\frac{x}{d} ; Y=\frac{y}{d} ; U=\frac{u}{u_{0}} ; V=\frac{v}{u_{0}}$

$$
\Psi=\frac{\psi}{u_{0} d} ; \omega=\frac{\Omega d}{u_{0}} ; \theta=\frac{\lambda\left(T-T_{a}\right)}{\emptyset d} ; R e=\frac{\rho v_{0} d}{\mu} ; G r=\frac{g \beta \emptyset d^{4}}{\lambda V^{2}}(6)
$$

\section{Initial and Boundary Conditions:-}

By introducing the non dimensional parameters into the physical boundary conditions illustrated in fig.1, the following non dimensional boundary conditions are obtained:

$$
\begin{gathered}
\theta=0 ; U=V=\omega=\psi=0 \text { at } \tau=0 \\
\text { at } \tau>0
\end{gathered}
$$

The boundary conditions, associated with the problem are as follows:

$$
\begin{gathered}
X=\text { Sand } 0 \leq Y \leq \frac{H_{B}}{d}: \theta=0 ; V=0 ; U=0 ; \omega=-\left.\frac{\partial^{2} \psi}{\partial X^{2}}\right|_{X=S} ; \psi=0 \\
X=\text { Sand } \frac{H_{B}}{d} \leq Y \leq \frac{\left(H_{B}+e\right)}{d}: \theta=0 ; V=0 ; U=-1 ; \omega=0 ; \psi=-Y+D \\
X=S a n d \frac{\left(H_{B}+e\right)}{d} \leq Y \leq \frac{H}{d}: \theta=0 ; V=0 ; U=0 ; \omega=-\left.\frac{\partial^{2} \psi}{\partial X^{2}}\right|_{X=S} ; \psi=0 \\
Y=0 \text { and } 0 \leq X \leq S: U=V=\psi=0 ;\left.\frac{\partial \theta}{\partial Y}\right|_{Y=0}=0 ; \omega=-\left.\frac{\partial^{2} \psi}{\partial Y^{2}}\right|_{Y=0} \\
Y=\operatorname{Aand} K \leq X \leq S: U=V=0 ; \psi=0 ;\left.\frac{\partial \theta}{\partial Y}\right|_{Y=A}=0 ; \omega=-\left.\frac{\partial^{2} \psi}{\partial Y^{2}}\right|_{Y=A}(7) \\
X=0 \text { and } 0 \leq Y \leq D: U=V=\psi=0 ; \omega=-\left.\frac{\partial^{2} \psi}{\partial X^{2}}\right|_{X=0} ;\left.\frac{\partial \theta}{\partial X}\right|_{X=0}=\left(\eta_{e l}-\tau_{g l} \alpha_{P V}\right) \\
X=0 \text { and } \leq \leq Y \leq A: U=V=\psi=0 ; \omega=-\left.\frac{\partial^{2} \psi}{\partial X^{2}}\right|_{X=0} ;\left.\frac{\partial \theta}{\partial X}\right|_{X=0}=\left(\eta_{e l}-\tau_{g l} \alpha_{P V}\right)-\left(\frac{q_{r_{P V, a b s}}}{\emptyset}\right) \\
X=K a n d D \leq Y \leq A: U=V=0 ; \psi=0 ; \omega=-\left.\frac{\partial^{2} \psi}{\partial X^{2}}\right|_{X=K} \\
X=\operatorname{Kand} \leq Y \leq A:-\left.\frac{\partial \theta}{\partial X}\right|_{X=K}=\left(\tau_{g l} \alpha_{P V} \alpha_{a b s}\right)-\left(\frac{q_{r_{a b s}, P V}}{\emptyset}\right)
\end{gathered}
$$

At the outlet of the chimney:

$$
\begin{gathered}
\text { If } \mathrm{V}(\mathrm{X}, \mathrm{A}) \geq 0 \quad \operatorname{and} \vec{V}(X, A) \cdot \vec{n}>0 \\
Y=\text { Aand } 0 \leq X \leq K: U=0 ;\left.\frac{\partial V}{\partial Y}\right|_{Y=A}=\left.\frac{\partial \theta}{\partial Y}\right|_{Y=A}=\left.\frac{\partial \omega}{\partial Y}\right|_{Y=A}=\left.\frac{\partial \psi}{\partial Y}\right|_{Y=A}=0 \text { (8) } \\
\text { If } \mathrm{V}(\mathrm{X}, \mathrm{A}) \leq 0 \text { and } \vec{V}(X, A) \cdot \vec{n}<0 \\
Y=\text { Aand } 0 \leq X \leq K: U=\theta=0 ;\left.\frac{\partial V}{\partial Y}\right|_{Y=A}=\left.\frac{\partial \omega}{\partial Y}\right|_{Y=A}=\left.\frac{\partial \psi}{\partial Y}\right|_{Y=A}=0 \\
q_{r_{a b s, P V}}=\sigma \frac{\left(T_{P V}^{4}-T_{a b s}^{4}\right)}{\left(\frac{1}{\varepsilon_{P V}}+\frac{1}{\varepsilon_{a b s}}-1\right)} ; q_{r_{P V, a b s}}=\sigma \frac{\left(T_{a b s}^{4}-T_{P V}^{4}\right)}{\left(\frac{1}{\varepsilon_{P V}}+\frac{1}{\varepsilon_{a b s}}-1\right)}
\end{gathered}
$$




\section{Heat Transfer:-}

From the engineering viewpoint, the most important concern is heat transfer through the PV cells modules, the heated walls. These are best represented by Nusselt number. The local Nusselt number on the front side plate and the inner absorber plate of the chimney are given by:

$$
\begin{gathered}
X=0 \text { and } 0 \leq Y \leq A: \mathrm{Nu}_{\mathrm{PV}}(\mathrm{Y})=\frac{\emptyset d}{\lambda\left(T_{P V}(0, Y)-T_{a}\right)}=\frac{1}{\theta_{P V}(0, Y)} \\
X=K \text { and } D \leq Y \leq A: \mathrm{Nu}_{\mathrm{abs}(\mathrm{Y})}=\frac{\emptyset \mathrm{d}}{\lambda\left(\mathrm{T}_{\mathrm{abs}(\mathrm{K}, \mathrm{Y})}-\mathrm{T}_{\mathrm{a}}\right)}=\frac{1}{\theta_{\mathrm{abs}(\mathrm{K}, \mathrm{Y})}}(10)
\end{gathered}
$$

The electrical efficiency of the solar PV cells is given as follows:

$$
\begin{gathered}
\eta_{e l}=\eta_{r e f}+\beta_{p v}\left(\overline{T_{P V}}-298\right)+\gamma \log \left(\frac{\emptyset}{1000}\right) \\
\overline{T_{P V}}=\frac{1}{H} \int_{0}^{H} T_{P V(0, y)} d y
\end{gathered}
$$

The mass flow rate in the channel is expressed:

$$
\dot{m}=\rho V_{0} \int_{0}^{K} W(X, A) d X
$$

Where $\overline{T_{P V}}$ is the average absolute temperature of the PV plate

\section{Numerical Method:-}

The non linear partial differential governing equations, (1-3), were discretized using a finite difference technique. The first and second derivatives of the diffusive terms were approached by central differences while a second order upwind scheme was used for the convective terms to avoid possible instabilities frequently encountered in mixed convection problems. The integration of equations (2-3) was assured by theThomas algorithm. At each time step, the Poisson equation, Eq. (4), was treated by using the Point Successive Under-Relaxation method (PSUR) with an optimum under-relaxation coefficient equal to 0.8 for the uniform grid $(101 \times 101)$ adopted in the present study. Convergence of iteration for stream function solution is obtained at each time step .The following criterion is employed to check for a steady-state solution. Convergence of solutions is assumed when the relative error for each variable between consecutive iterations is recorded below the convergence criterion $\varepsilon$ such that $\Sigma \mid\left(\emptyset_{i, j}^{n+1}-\emptyset_{i, j}^{n}\right) /$ $\emptyset_{i, j}^{n+1} \mid<10^{-5}$ where $\phi$ stands for $\psi, \Theta, \omega, n$ refers to time and $i$ and $j$ refer to space coordinates. The time step used in the computations is $1.10^{-5}$. Grid independency solutions are assured by comparing different grid meshes for the highest Grashof and Reynolds numbers used in this work $\left(\mathrm{Gr}=10^{6}\right.$ and $\left.\mathrm{Re}=200\right)$ in tab1. The vorticity

\begin{tabular}{|c|c|c|c|c|c|}
\hline stage & Gridsize & $\theta_{\mathrm{PV} \max }$ & Change $(\%)$ & NuS $_{\text {PVmoy }}$ & Change $(\%)$ \\
\hline \multirow{3}{*}{$\begin{array}{l}\mathrm{M}=100 \\
\mathrm{~N} \text { varied }\end{array}$} & $82 \times 102$ & 0.12504 & - & 20,34426 & - \\
\hline & $102 \times 102$ & 0.12496 & 0.06398 & 20,30866 & 0.17499 \\
\hline & $122 \times 102$ & 0.12483 & 0.10403 & 19,96541 & 1.69017 \\
\hline \multirow{3}{*}{$\begin{array}{l}\mathrm{N}=100 \\
\mathrm{M} \text { varied }\end{array}$} & $102 \times 82$ & 0.12598 & - & 20,31443 & - \\
\hline & $102 \times 102$ & 0.12496 & 0.01588 & 20,30866 & 0.02840 \\
\hline & $102 \times 122$ & 0.12470 & 0.20807 & 20,23774 & 0.34921 \\
\hline
\end{tabular}
computational formula of (Woods, 1954) for approximating wall vorticity was used: $\omega_{P}=\frac{1}{2} \omega_{P+1}-\frac{3}{\Delta \eta^{2}}\left(\psi_{P+1}-\right.$ $\left.\psi_{P}\right)$, where $\psi_{P}$ and $\psi_{P+1}$ are stream function values at the points adjacent to the boundary wall; $\mathrm{n}$ the normal abscise on the boundary wall.

Tab.1:-Grid independency solutions

\section{Results and Discussion:-}

\section{Validation:-}

In order to test the computer code developed for this study, the problem of a ventilated cavity heated by a uniform heat flux from its vertical left wall while the remaining walls are considered perfectly insulated was studied. Very good agreement is obtained between the test problem solution and the ventilated cavity solutions according to the work of (Raji et al., 2008). Where the system is submitted to an imposed flow of fresh air, parallel to the horizontal walls, entering and leaving the cavity from two opposing openings located at the middle of the vertical plates, with no slip boundary conditions applied to all the walls. The Reynolds number, Re was set at 10, for Raleigh number Ra set at 0 .The numerical analysis predicted values of streamlines and isotherms together with ventilated cavity results are shown in fig.2. 


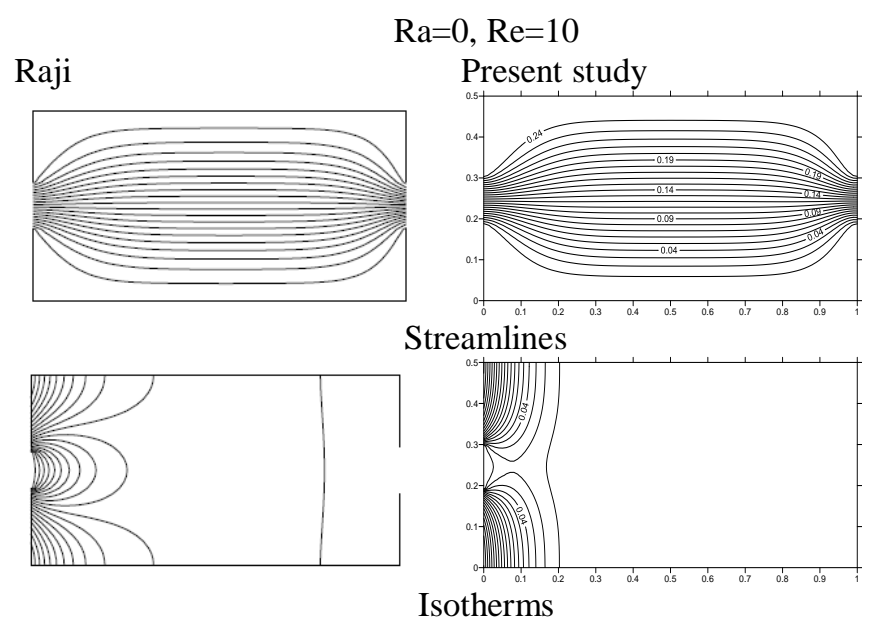

Fig.2:- Comparison of streamlines and isotherms

Flow and Thermal Fields 'Characteristics:-

In the solar chimney integrated at the south façade of the building, the temperature distribution and the flow fields of the inlet jet and buoyancy force which induce natural convection have been analyzed numerically. The effect of Reynolds number on the flow structureand temperature distribution is shown in Fig.3 (a-c). Thestreamlines and the isotherms are presented for steady stateflows obtained for $\mathrm{Gr}=10^{4}$ and values of the Reynoldsnumber ranging between 20 and 100. For $\mathrm{Re}=20$, the analysis of the streamlinesin fig. 3 (a) reveals a complex structure at the bottom part of the chimney where the simultaneous presenceof a closed cells and the open lines are observed. Fig.3 (a-c) indicates the fluid flow patterns inside the room and the chimney. As shown, the streamline contours exhibit the circulation patterns as the fluid motion which is affected by PV cells and the absorber heated plates. The flow characteristics show the simultaneous existence of the natural convection cells and the open lines of the forced convection for the low values of the Reynolds number at the outlet of the chimney . The direction of flow, due to the thermal buoyancy force, is clockwise in this geometry as observed in the channels. The plot shows that from the bottom of the chimney, the inlet air flow converges especially towards the active PV cells plate which is heated by uniform flux, and the buoyancy forces drive the heated air to the outlet of the chimney. For increasing Reynolds number, the upper closed cells appear in the room near the entry opening, above the open lines. In fact, the heated portion of the absorber plate, located above the opening of the chimney, imposes a clockwise circulation. The distribution of the temperature field shows that the room space far from the chimney is at the temperature of the external flow. The upper closed cells will play an increasingly important role by increasing Re sincethe more intense is the forced flow, the more important is its negative (positive) effect on the natural convection flow in the room and in the upper (lower) part of the solar chimney. When the forced flow overcomes the effect of natural convection in the chimney, the open lines are aspired by the solar PV cells and the absorber heated plates as indicated in Fig.3 (c)for $\operatorname{Re}=100$.

$\mathbf{a}$

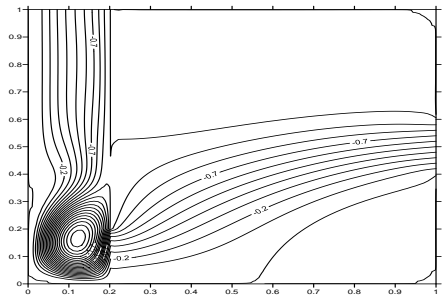

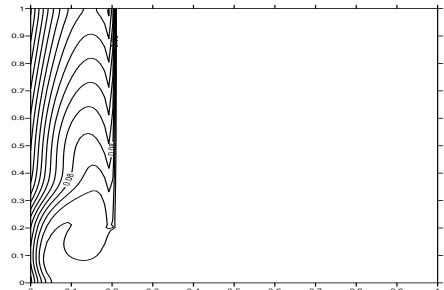


b
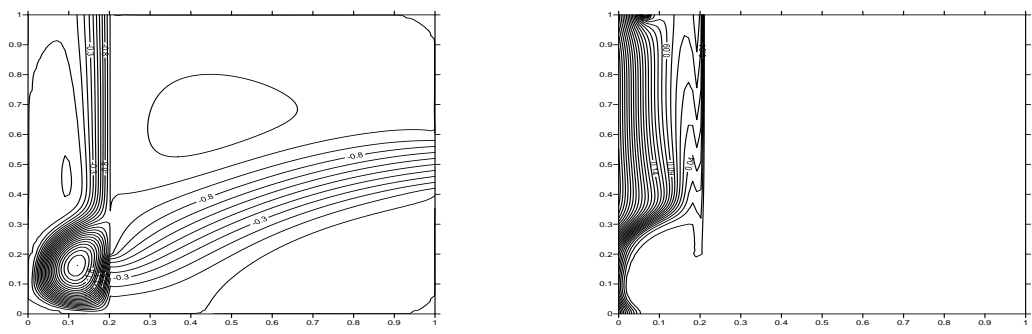

c
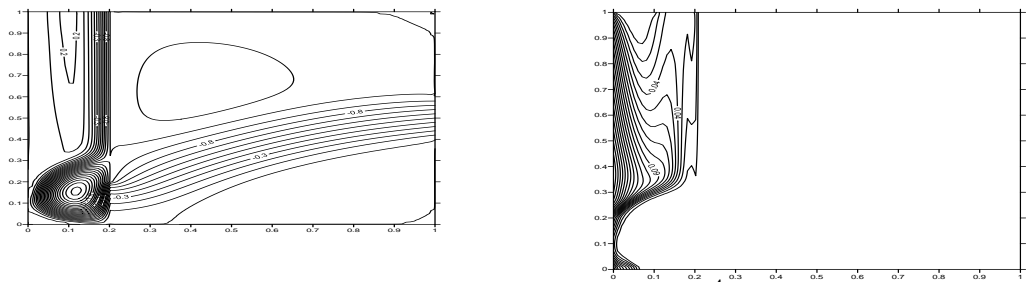

Fig.3:-Streamlines and isotherms obtained for $\mathrm{Gr}=10^{4^{2}}$ and different values of $\operatorname{Re}$ : (a) $\operatorname{Re}=20$, (b) $\operatorname{Re}=50$; (c)

$$
\mathrm{Re}=100
$$

The corresponding isotherms are tight in the vicinity of the solar cells and the absorber heated plates testifying to a noticeable increase in convective heat exchange. A further increase of the Reynolds number acts by increasing the aiding role of forced and natural convection in the chimney integrated with thesouth façade of the building. Hence, the intensification of the forced flow leads to an increase in the role played by the open lines as shown in Fig. 3(bc).

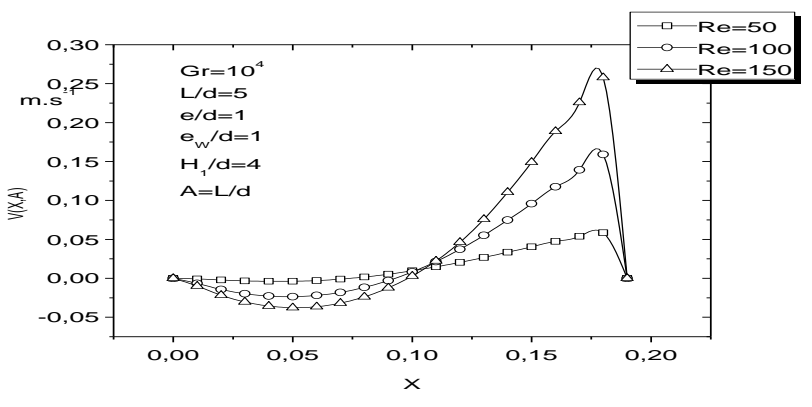

Fig.4:- Variation of vertical component of velocity for various Reynolds numbers

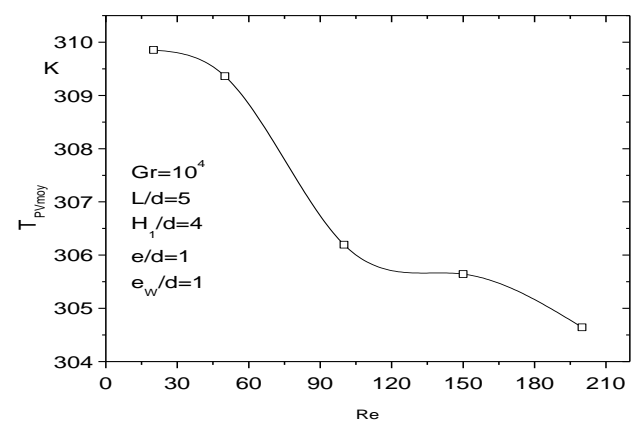

(a) PV cells plate

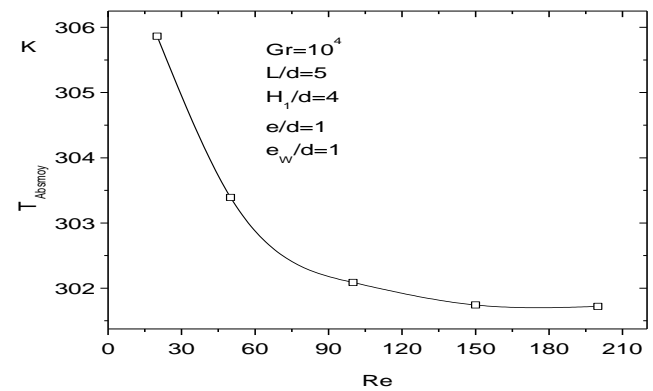

(b) Absorber Plate

Fig.5:-Variation of mean temperature of PV cells and absorber plates versus Reynolds number

It can also be seen that the forced flow crosses the room directly from an inlet opening to the outlet opening at the top of the solar chimney without being constrained to go along the heated absorber plate before reaching the exit, which favors the formation of open lines in the upper part of the channel. The analysis of the isotherms shows that 
the room is maintained at ambient temperature and cold due to passive cooling. Consequently, fig.5 (a-b) showed that the mean temperature of the PV cells and the absorber heated plates are both decreasing functions of Reynolds number.

Fig.4 indicates that the outlet velocity is an increasing function of Reynolds number. Then, the outlet airflow velocity increases and overtakes a maximal value in the middle of the width of the chimney before decreasing to attain the minimal value near the insulated absorber plate as shown in fig.4.

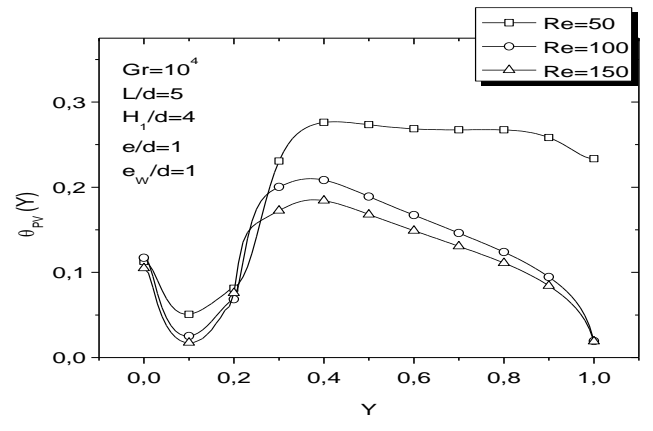

(a) PV cells plate

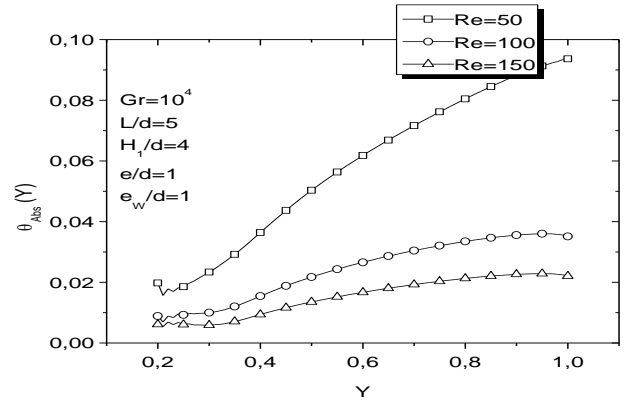

(b)Absorber plate

Fig.6:-Variation of dimensionless temperature of PV cells and absorber plates for different values of Reynolds number

Fig.6 (b) indicates, except the fluctuations near the chimney entry opening, the dimensionless temperature along the absorber plate is an increasing function of Reynolds number. Otherwise, the dimensionless temperature along the heated PV cells plate decreases firstly at its bottom before increasing to reach to the maximum value and again decreasing to attain the minimal value, indicated in fig.6 (a) for a fixed Reynolds number. This tendency is illustrated in fig.7 (a) in which local Nusselt number is defined as the inverse value of the dimensionless temperature.

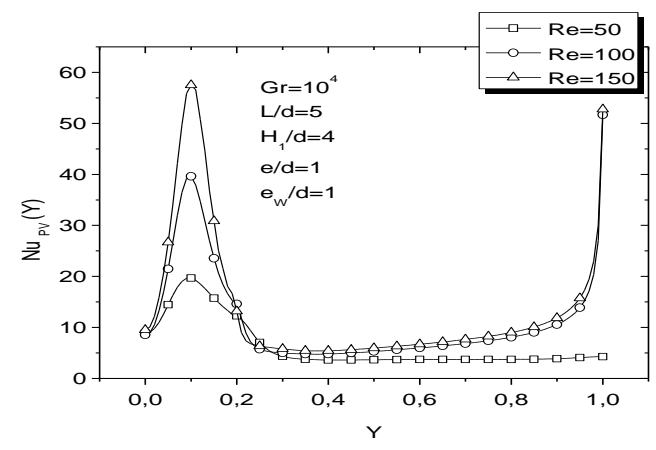

(a) PV cells plate

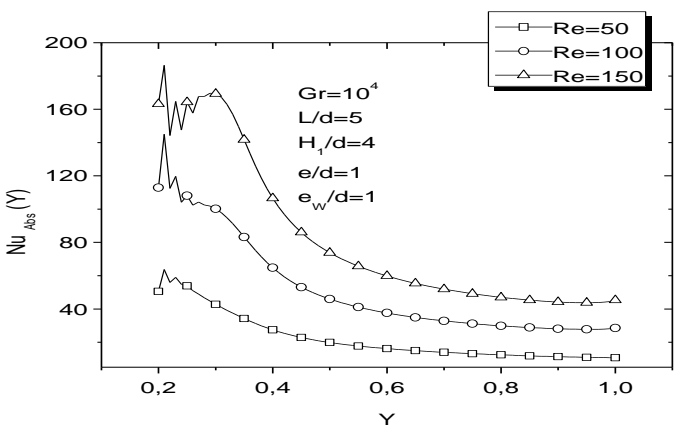

(b) Absorber plate

Fig.7:-Variation of local Nusselt number along the PV cells and absorber plates for various Reynolds numbers

Hence, the local Nusselt number along the PV cells plate, for a fixed Reynolds number, increases to reach to the maximal value, before decreasing and then increasing again to attain the same maximum value. 


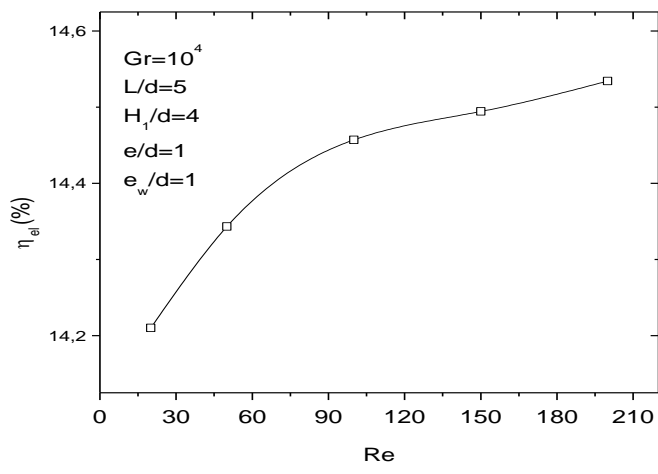

(a) PV cells' electrical efficiency

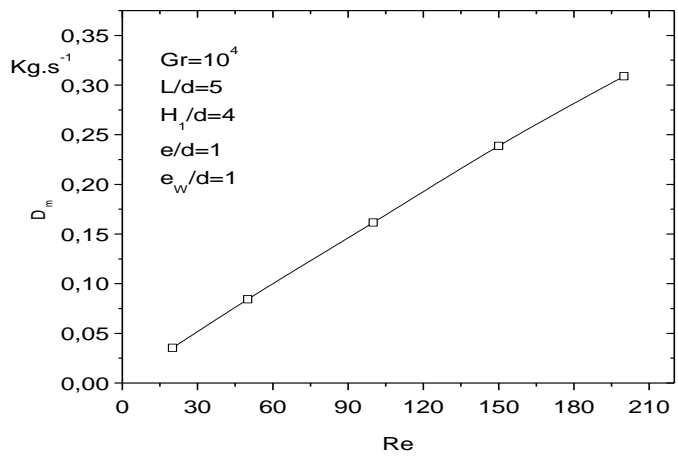

(b) Mass flow rate

Fig.8:-Variation ofthe PV cells' electrical efficiency and the mass flow rate versus Reynolds number

This situation can be explained by the fact that at the entry opening of the chimney the PV cells plate as the absorber plate are cooledby fresh air. This is the fluctuations observed of the local Nusselt number along the absorber plate before decreasing along the heated wall, as shown in fig.7 (b). Fig. 8 (a-b) indicates respectivelythe variation of the PV cells 'electrical efficiency and mass flow rate versus Reynolds number. Both, mass flow rate as the PV cells' electrical efficiency are increasing functions of Reynolds number.

\section{Effect of Grashof Number:-}

In order to understand the effect of Grashof number on fluid flow and heat transfer phenomena, a parametric study of Grashof number varying from $10^{3}$ to $10^{6}$ is carried out for a fixed Reynolds number $\mathrm{Re}=100$.

a

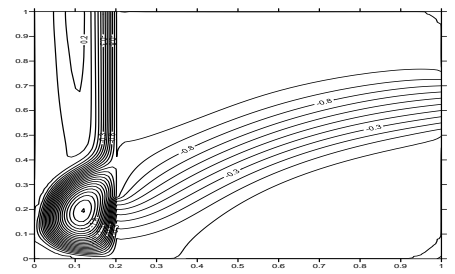

$\mathrm{b}$

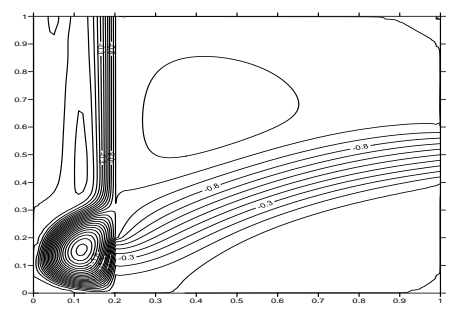

$\mathrm{c}$

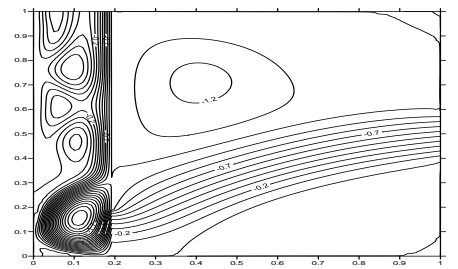

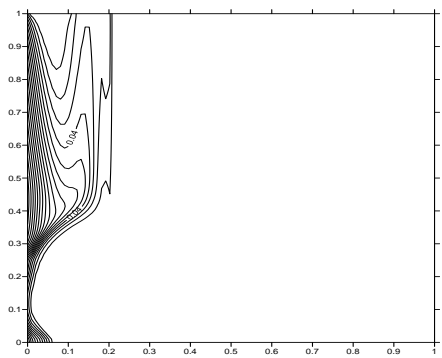
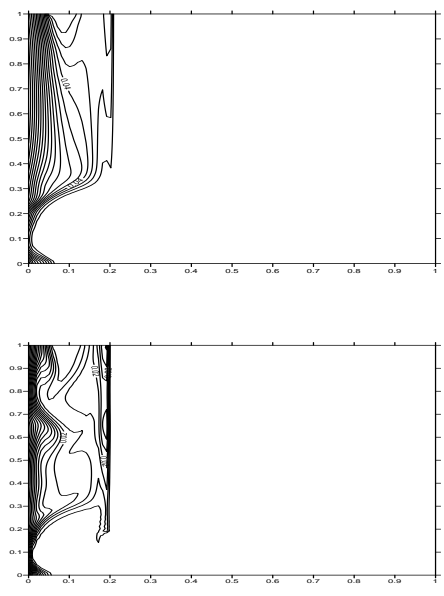

Fig.9:- Streamlines and isotherms obtained for $\mathrm{Re}=100$ and different values of $\mathrm{Gr}$ : (a) $\mathrm{Gr}=10^{3}$, (b) $\mathrm{Gr}=10^{5}$; (c) $\mathrm{Gr}=10^{6}$ 
At the low value of the Grashof number, such as $\mathrm{Gr}=10^{3}$, the forced convection due to the driven force dominates the flow structure in the integrated solar chimney, fig. 9(a). At this order of Grashof number, the inertia force of the fluid is dominant compared to the buoyancy force. As shown by streamlines in Fig. 9(a-c), air circulation inside the chimney is very weak at lowGrashof number and increases with the Grashof number. A high insolation effect increases the air circulation inside the chimney and the isotherms become more distorted. As the Grashof number increases to $\mathrm{Gr}=10^{4}$, the Richardson number $\mathrm{Ri}=1$, the inertia and buoyancy forces balance each other, which then results in a mixed convection, fig. 3 (c). When the Grashof number further increases to $\mathrm{Gr}=10^{6}$, $(\mathrm{Ri}=100)$ the buoyancy force becomes the dominant mechanism driving the convection of the air, and the flow is in the regime of natural convection in the room and chimney. The closed cells appear in the chimney and the back flow phenomenon is observed, Fig. 9(c). The isotherms plotted for increasing Grashof number are represented in fig.9 (a-c). One can observe that the isotherms are greatly distorted near the solar PV cells andthe absorber plates. This tendency indicates the effect of the increase intheGrashof number on the heat transfer process.Fig.10 (a-b) shows the variation of the mean dimensionless temperature along the active plates versus the heated flux. The dimensionless temperature increases and reaches the maximum value for the low value of the heated flux before decreasing for the high intensity of incident solar radiation at the fixed Reynolds number. Hence in fig.11 (a-b), the local Nusselt number along the PV cells and the absorber plates is an increasing function of Grashof number. In fig.12 (a), the mass flow rate is decreasing, when the incident solar radiation is increasing.

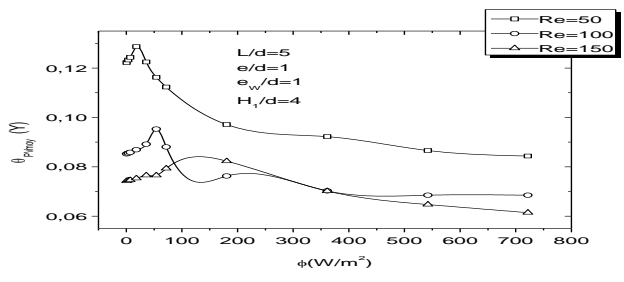

(a) PV cells plate

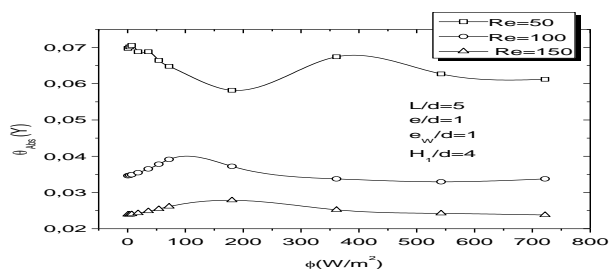

(b) Absorber plate

Fig.10:-Variation of mean dimensionless temperature along the PV cells and the absorber plates versus heated flux

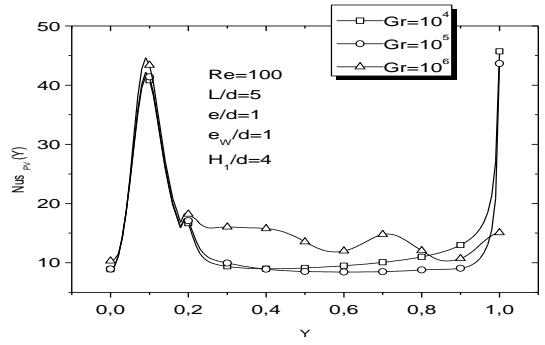

(a) PV cells plate

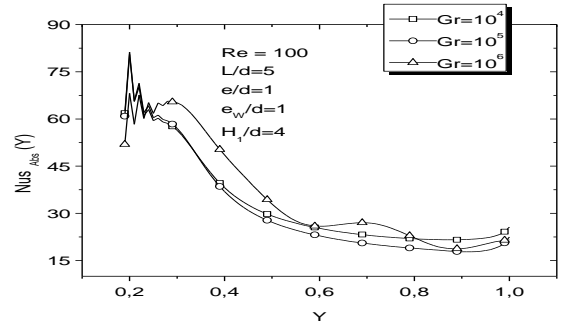

(b) Absorber plate

Fig.11:-Variation of local Nusselt number along the PV cells and the absorber plates for various Grashof number

This situation indicates that for increasing grashof number or incident heated flux, the back flow phenomenon appears in the chimney. The same results are obtained by (S.L.Sinha et al.2000) in the numerical simulation of a two-dimensional room air flow with and without buoyancy that the intensity of the recirculation zone in the cavity increases as Grashof number Gr increases to $10^{8}$.In fig. 12 (a) the vertical component of the velocity decreases at the outlet of the chimney, when the Grashof number increases. This variation is illustrated by the back flow phenomenonestablishmentforincreasingGrashof number. Consequently, the mass flow rate is decreasing when the Grashof number related to the incident solarradiation is increasing, fig.12 (b). 


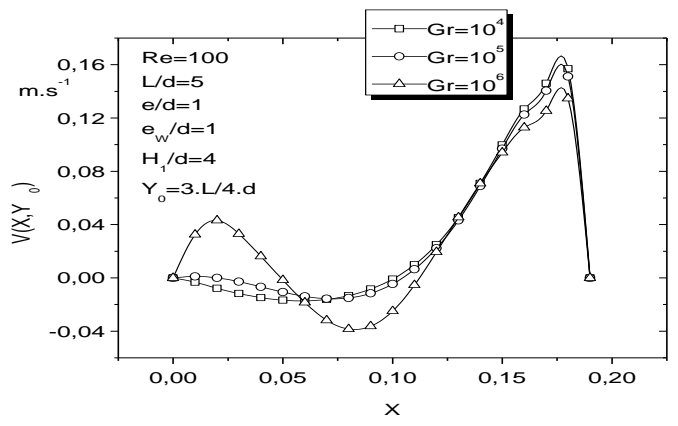

(a) Vertical velocity component

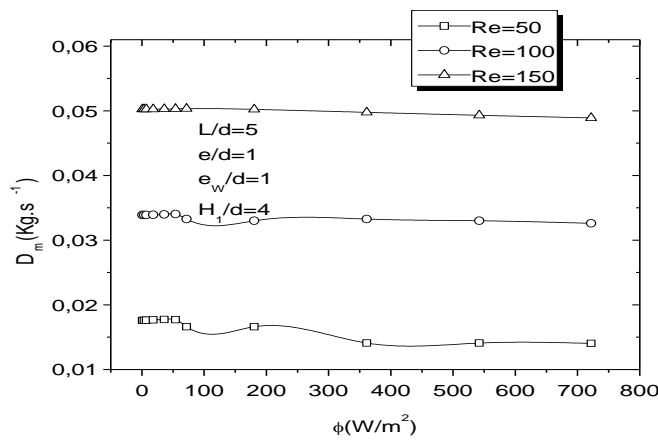

(b)Mass flow rate

Fig. 12:-Variation of vertical velocity component and the mass flow rate versus the heated flux

\section{Effect of Chimney Width (d), Absorber Variable Height $\left(\mathrm{H}_{1}\right)$ and InletOpening (e):-}

Fig.13 (a-b) shows the streamline and isotherm plots in the chimney and room.For $\mathrm{H}_{1} / \mathrm{d}$ equal to 4 , the Raleigh Bernard natural convective cells appear in the room above the open lines of forced convection.

a
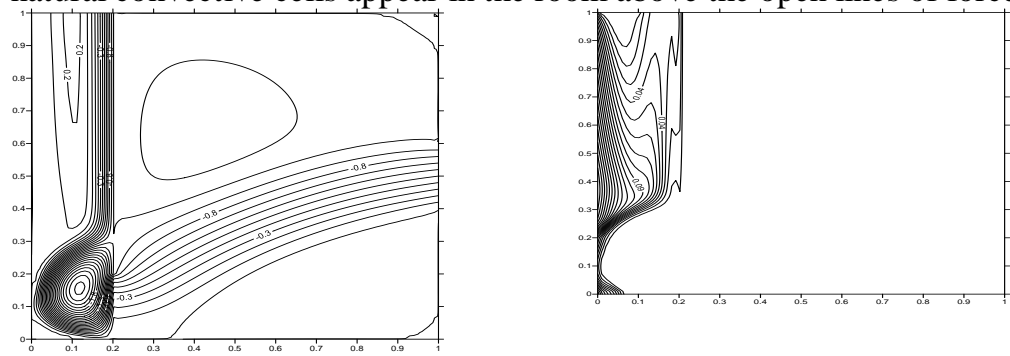

b
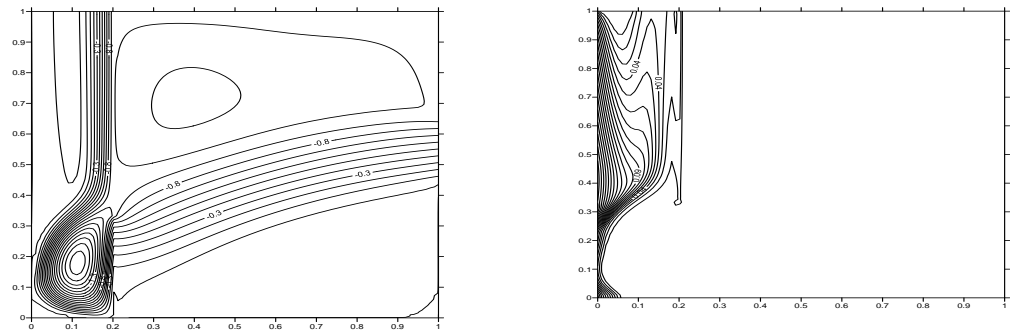

$\mathrm{c}$
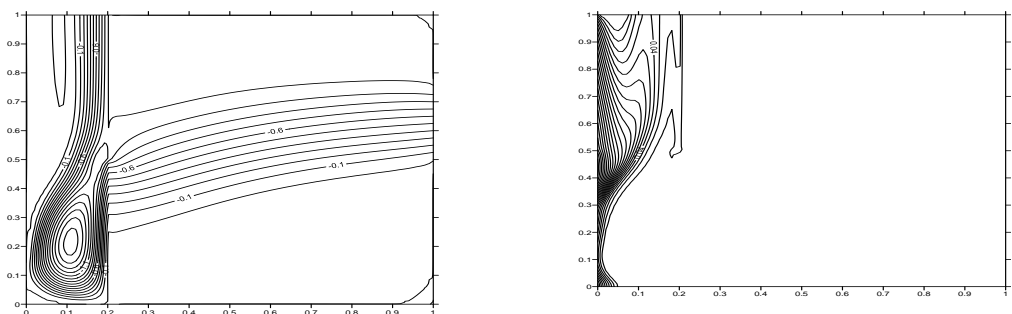

Fig.13:- Streamlines and isotherms obtained for $\mathrm{Re}=100, \mathrm{Gr}=10^{4}$ and different value of absorber plate height: (a) $\mathrm{H}_{1} / \mathrm{d}=4$, (b) $\mathrm{H}_{1} / \mathrm{d}=3$, (c) $\mathrm{H}_{1} / \mathrm{d}=2$

The simultaneous existence of the clockwise cells and the open cells indicates that mixed convection is established. Then for the low value of the absorber height in the chimney, the big upper closed cells disappear in the room and passive cooling is obtained, hence forced convection is dominant. The natural convective recirculation cells located at the entry of the chimney disappear progressively in favor for the open lines in the chimney, when the height of the absorber plate decreases. This situation indicates the principal importance of the PV Tromb wall window configuration. The inner part of the PV cells plate becomes more transparent to the sunshine in the room and plays a light role during day time. The isothermal lines are very distorted in the chimney and are more tightened at the vicinity of the PV cells heated plate testifying to a noticeable increase in convective heat exchange, when the 
absorber plate height $\mathrm{H}_{1}$ is increasing. Fig.14, indicates that the outlet velocity is decreasing in the first middle of the width of the chimney when the absorber plate height is increasing, before increasing in the second middle of the width of the chimney to reach the maximal value and then decreasing along the upper part of the absorber plate to attain the minimal value. This tendency shows that the no sleep boundary condition along the absorber plate is verified. In fig.15 (a), the local Nusselt number along the PV cells plate, increases when the height of the absorber plate increases and then decreases to attain the minimal value, before increasing again to reach the high value at the top. This heat transfer phenomenon illustrates the main interest of the variable absorber height in the PV Tromb wall window. The variation of the absorber plate height induces the variation of the solar chimney entry opening $\left(\mathrm{e}_{\mathrm{W}}\right)$. The fig.15 (b) shows that theair temperature in the chimney is stratified along the width of the chimney. Fig.16 (a-c) shows the chimney width (d) effect on streamline and the isothermal line distribution. One can observe that for the low value of the chimney width (d), the big closed cells between the absorber plate and the cold wall of the room appears. There is a presence of the parallel open lines in the chimney.

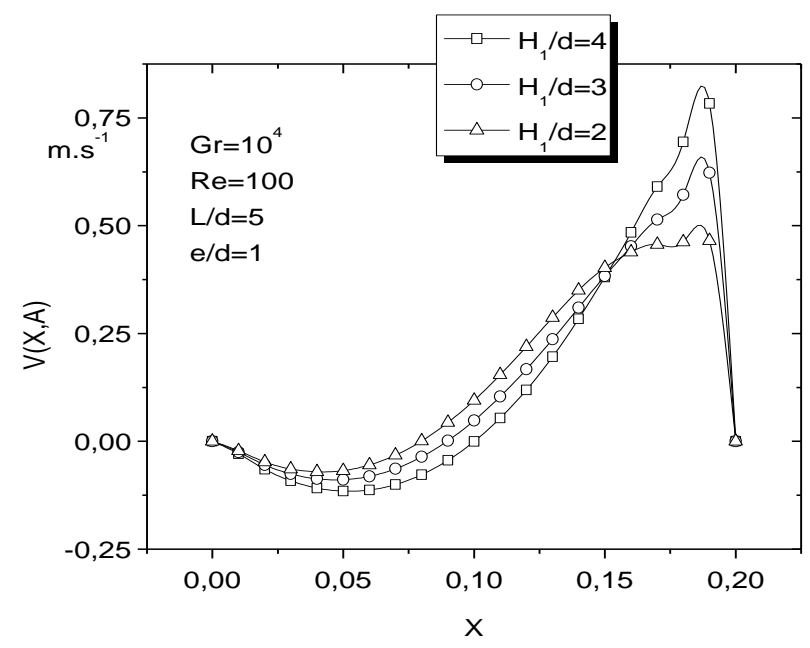

Fig.14:-Variation of vertical component of velocity for various absorber plate height

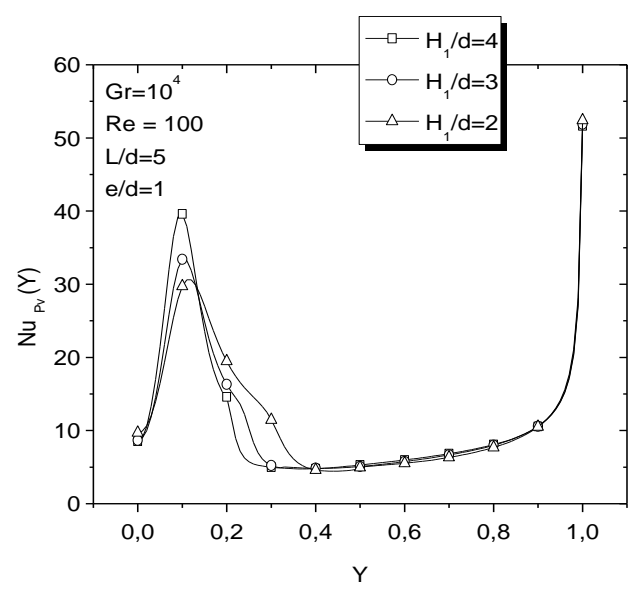

(a)

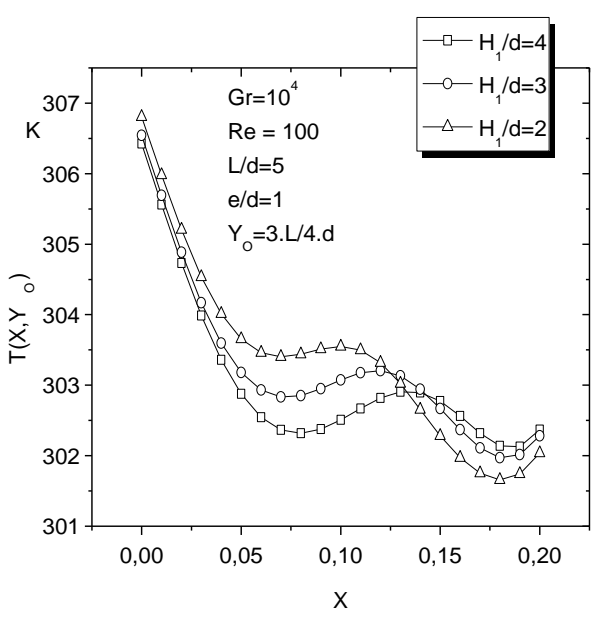

(b)

Fig.15:- Variation of local Nusselt number and the temperature along the PV cells plate and the width the chimney for various absorber plate height

The simultaneous existence of the closed recirculation cells and open lines prove mixedconvection in the room. The isotherm patterns are very tight in the vicinity of the PV cells plate, consequently; thesolar PV cells are more heated. 
One can note that, when the width (d) increases, the intensityof recirculation disappears progressively in the room, and then appears in the solar chimney the closed cellsof natural convection and the back flow phenomenon manifestation.

a
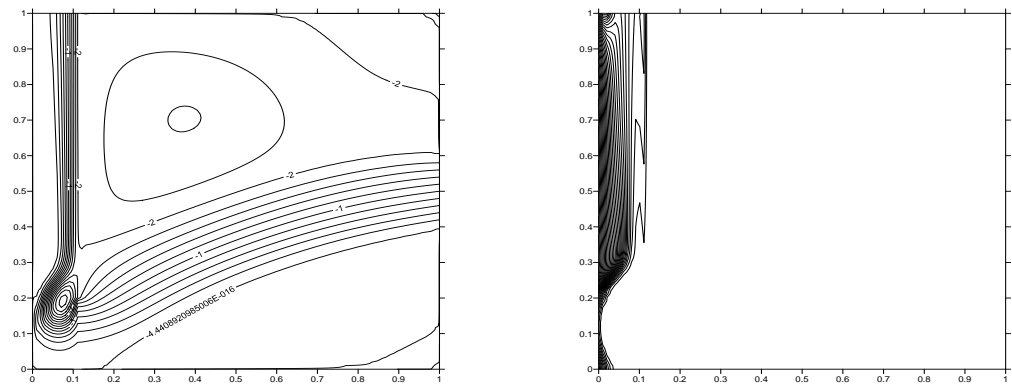

$\mathrm{b}$
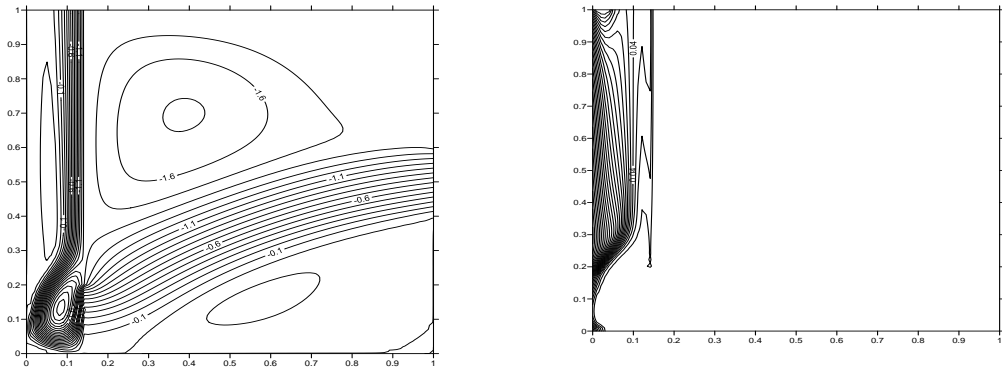

$\mathrm{c}$
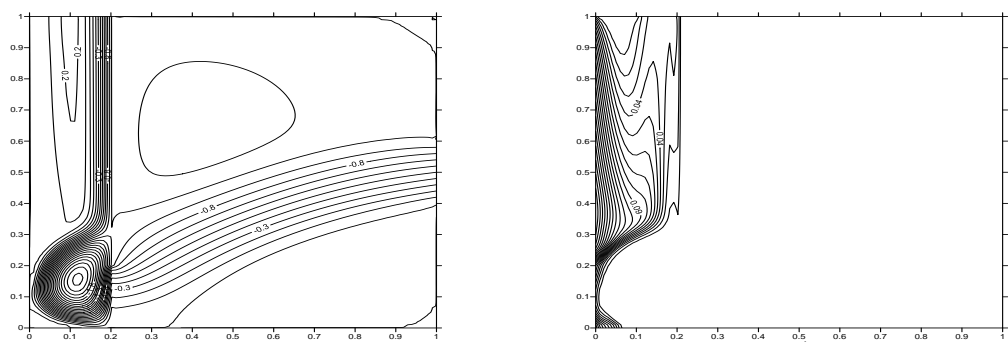

Fig.16:-Streamlines and isotherms obtained for $\mathrm{Re}=100, \mathrm{Gr}=10^{4}$ and different values of the chimney width: (a) $\mathrm{d}$ $=2.5 \cdot 10^{-2} \mathrm{~m}$; (b) $\mathrm{d}=3.5 \cdot 10^{-2} \mathrm{~m} ;$ (c) $\mathrm{d}=5.10^{-2} \mathrm{~m}$

The small closed cells located at the entry of the chimney, increases progressively and prevents the open lines from exiting through the chimney. Fig.17(a-b) and the fig.18 (a-b) show respectively that the variation of the local Nusselt number along the PV cells and absorber plates is significantly affected by the chimney width (d) and the inlet opening size (e) effects.
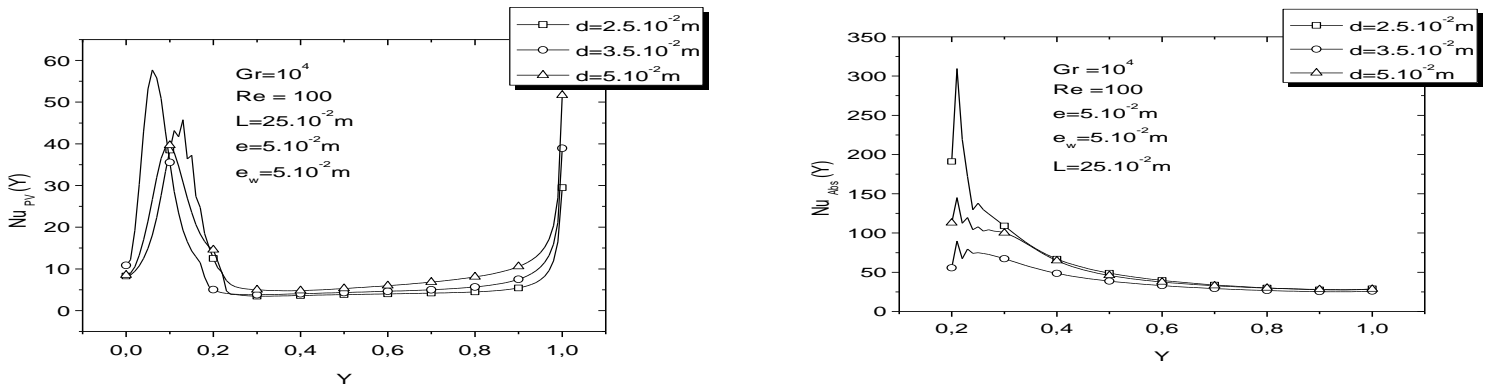

Fig.17:-Variation of local Nusselt number along the PV cells and absorber plates for various values of the chimney width 


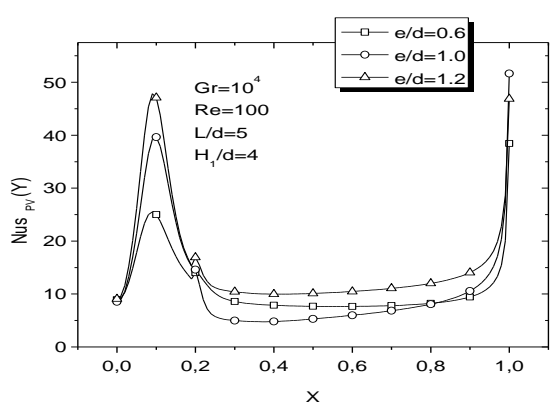

(a) PV cells plate

Fig.18:- Variation of local Nusselt number along the PV cells and absorber plates for various values of the inlet opening size

\section{Conclusion:-}

The numerical investigation in this study allowed the authors to know that the air flow in the hybrid photovoltaicthermal chimney integrated with the south façade of the building for the lowest value of Reynolds number is natural convection while it is forced convection for the highest value of Reynolds number. The air flow role is to extract the excess heat along the solar PV cells and absorber plates in thechimney. The flow analysis in the solar chimney has given severalpossibilitiesforutilizingPVTrombwallwindow as solar chimney for the low values of inlet velocity or Reynolds number. This device gives possibilities to reduce the energy charge for air conditioning andprovides passive cooling in the room. Within the investigated parameter ranges, the following conclusions can be drawn:

- For the low value of the chimney width, the solar PV cells are more heated, hence the electrical efficiency decreases.

- For the low value of the absorber plate height, there is no circulation closed cells in the room

- The solar chimney is able to provide ventilation to the building during daylightwithout recirculation of room air.

- PV Tromb wallwindowgives the possibility to decrease energy consumption in buildings and provides passive cooling.

- PV Tromb wall window uses solar energy to ventilate and provide thermal comfort in buildings.

Nomenclature:-

\begin{tabular}{|l|l|}
\hline $\mathrm{C}_{\mathrm{P}}$ & Specific heat $\left(\mathrm{J}_{\mathrm{kg}} \mathrm{kg}^{-1} \cdot \mathrm{K}^{-1}\right)$ \\
\hline $\mathrm{H}$ & Building height $\left(\mathrm{H}=\mathrm{H}_{\mathrm{A}}+\mathrm{H}_{\mathrm{B}}+\mathrm{e}\right)(\mathrm{m})$ \\
\hline $\mathrm{L}$ & Building length $(\mathrm{m})$ \\
\hline $\mathrm{H}_{1}$ & Absorber height $(\mathrm{m})$ \\
\hline $\mathrm{d}$ & Chimney width $(\mathrm{m})$ \\
\hline $\mathrm{A}$ & Aspect ratio of the chimney $(\mathrm{A}=\mathrm{H} / \mathrm{d})$ \\
\hline $\mathrm{S}$ & Aspect ratio of the building $(\mathrm{S}=\mathrm{L} / \mathrm{d})$ \\
\hline $\mathrm{e}_{\mathrm{W}}$ & Chimney entry opening $(\mathrm{m})$ \\
\hline $\mathrm{e}$ & Inlet opening size $(\mathrm{m})$ \\
\hline $\mathrm{D}$ & Aspect opening ratio $(\mathrm{D}=\mathrm{e} / \mathrm{d})$ \\
\hline $\mathrm{K}$ & Chimney width aspect ratio $(\mathrm{K}=(\mathrm{L}-\mathrm{d}) / \mathrm{d})$ \\
\hline $\mathrm{D}_{\mathrm{m}}$ & Mass flow rate $\left(\mathrm{Kg} \cdot \mathrm{s}^{-1}\right)$ \\
\hline$q_{r 1}$ & Net radiative flux between $\mathrm{PV}$ plate and absorber plate $\left(\mathrm{W} \cdot \mathrm{m}^{-2}\right)$ \\
\hline$q_{r 2}$ & Net radiative flux between absorber plate and $\mathrm{PV}$ plate $\left(\mathrm{W} \cdot \mathrm{m}^{-2}\right)$ \\
\hline $\mathrm{g}$ & Gravitational acceleration $\left(\mathrm{m} . \mathrm{s}^{-2}\right)$ \\
\hline $\mathrm{n}$ & Coordinate in normal direction \\
\hline $\mathrm{t}$ & Time $(\mathrm{s})$ \\
\hline $\mathrm{T}$ & Temperature $(\mathrm{K})$ \\
\hline $\mathrm{T}_{\mathrm{a}}$ & Ambient air temperature $(\mathrm{K})$ \\
\hline $\mathrm{u}, \mathrm{v}$ & Velocity component in $\mathrm{x}$ and $\mathrm{y}$ directions $\left(\mathrm{m} . \mathrm{s}^{-1}\right)$ \\
\hline $\mathrm{U}, \mathrm{V}$ & Dimensionless velocity component in $\mathrm{X}$ and $\mathrm{Y}$ directions; $\mathrm{U}=\mathrm{u} / \mathrm{u}_{0}, \mathrm{~V}=\mathrm{v} / \mathrm{u}_{0}$ \\
\hline
\end{tabular}




\begin{tabular}{|c|c|}
\hline $\mathrm{W}$ & Outlet velocity \\
\hline $\mathrm{u}_{0}$ & Air inlet velocity $\left(\mathrm{m} \mathrm{s}^{-1}\right)$ \\
\hline $\mathrm{x}, \mathrm{y}$ & Coordinates defined in fig. $1(\mathrm{~m})$ \\
\hline $\mathrm{X}, \mathrm{Y}$ & Dimensionless spatial coordinates; $X=x / d, Y=y / d$ \\
\hline $\operatorname{Re}$ & Reynolds number : $R e=\frac{\rho v_{0}(2 e)}{\mu}$ \\
\hline $\operatorname{Pr}$ & Prandlt number : $\operatorname{Pr}=\mu C p / \lambda$ \\
\hline $\mathrm{Nu}$ & Nusselt number: $\quad N u=\frac{\emptyset d}{\lambda\left(T-T_{a}\right)}=\frac{1}{\theta}$ \\
\hline $\mathrm{Gr}$ & Grashof numberl dimensionless $G r=\frac{g \beta \emptyset d^{4}}{\lambda V^{2}}$ \\
\hline $\mathrm{Ri}$ & Thermal Richardson number $\left(R i=G r / \operatorname{Re}^{2}\right)$ \\
\hline \multicolumn{2}{|c|}{ Greek symbols } \\
\hline$\theta$ & Dimensionless temperature $\theta=\frac{\lambda\left(T-T_{a}\right)}{d \emptyset}$ \\
\hline$\tau$ & Dimensionless time $\quad \tau=\frac{v_{0 t}}{d}$ \\
\hline$\Psi$ & Dimensionless stream function: $\Psi=\frac{\psi}{d v_{0}}$ \\
\hline$\omega$ & Dimensionless vorticity: $\omega=\frac{\Omega d}{v_{0}}$ \\
\hline$\Omega$ & Vorticity $\left(\mathrm{s}^{-1}\right)$ \\
\hline$\psi$ & Stream function $\left(\mathrm{m} \cdot \mathrm{s}^{-2}\right)$ \\
\hline$\beta$ & Thermal expansion coefficient $\left(\mathrm{K}^{-1}\right)$ \\
\hline$\eta_{\mathrm{el}}$ & PV cells electrical efficiency (-) \\
\hline$\eta_{\text {ref }}$ & PV cells electrical efficiency at standard conditions(-) \\
\hline$\beta_{\mathrm{PV}}$ & PV cells temperature coefficient $\left(\mathrm{K}^{-1}\right)$ \\
\hline$\gamma$ & PV cellssolarirradiance coefficient (-) \\
\hline$\rho$ & Density of the air $\left(\mathrm{kg} \cdot \mathrm{m}^{-3}\right)$ \\
\hline$\lambda$ & Thermal diffusivity of the air $\left(\mathrm{W} \cdot \mathrm{m}^{-1} \cdot \mathrm{K}^{-1}\right)$ \\
\hline$\mu$ & Dynamic viscosity of the air $\left(\mathrm{kg} \cdot \mathrm{m}^{-1} \cdot \mathrm{s}^{-1}\right)$ \\
\hline$\phi$ & Solar radiation $\left(\mathrm{W} . \mathrm{m}^{-2}\right)$ \\
\hline$v$ & Cinematic viscosity $\left(\mathrm{m}^{2} . \mathrm{s}^{-1}\right)$ \\
\hline $\boldsymbol{\alpha}_{\mathrm{P}}$ & Absorptance coefficient of the absorber plate (-) \\
\hline$\tau_{\mathrm{gl}}$ & Transmittance coefficient of the glaze (-) \\
\hline $\boldsymbol{\alpha}_{\mathrm{PV}}$ & PV cells absorptance coefficient (-) \\
\hline $\boldsymbol{\tau}_{\mathrm{PV}}$ & PV cells transmittance coefficient (-) \\
\hline \multicolumn{2}{|c|}{ subscripts } \\
\hline PV & PV module \\
\hline Abs & Absorber Plate \\
\hline $\mathrm{f}$ & Fluid (air) \\
\hline $\mathrm{a}-\mathrm{Si}$ & Amorphous silicon \\
\hline moy & Mean \\
\hline c-Si & Cristalin silicon \\
\hline BIPV & Building integratedphotovoltaic \\
\hline
\end{tabular}

HVAC Hour Volume Air Conditionning

\section{References:-}


1. Agrawal, B., Tiwari, G.N., (2010),Optimizing the Energy and Exergy of Building Integrated Photovoltaic Thermal (BIPVT) Systems Under Cold Climatic Conditions, Applied Energy, Vol. 87, Issue 2, pp. 417-26.

2. Aste, N., Chiesa, G., Verri, F., (2008), Design, Development and Performance Monitoring of a PhotovoltaicThermal (PVT) Air Collector, Renewable Energy, Vol. 33, pp. 914-927.

3. Chae, Y.T., Kim, J., Park, H., Shin, B., 2014. Building energy performance evaluation of building integrated photovoltaic (BIPV) window with semi-transparent solar cells. Applied Energy 129, $217-227$.

4. Cheng, C.L., Jimenez, C.S.S., Lee, M., (2009), Research of BIPV optimal Tilted Angle, Use of Latitude Concept for South Orientated Plans, Renewable Energy, Vol. 34, Issue 6, pp. 1644-50.

5. Chow, T.T., Hand, J. W., Strachan, P. A., (2003), Building-Integrated Photovoltaic and Thermal Applications in a Subtropical Hotel Building, Applied Thermal Engineering, Vol. 23, pp. 2035-2049.

6. Chow, T.T., Fong, K.F., He, W., Lin, Z., Chan, A.L.S., 2007a. Performance evaluation of a PV ventilated window applying to office building of Hong Kong. Energy and Buildings 39, 643-650.

7. Chow, T.T., Qiu, Z., Li, C., 2009a. Potential application of "see-through" solar cells in ventilated glazing in Hong Kong. Solar Energy Materials \& Solar Cells 93, 230-238.

8. Han, J., Lu, L., Yang, H., 2010.Numerical evaluation of the mixed convective heat transfer in a double-pane window integrated with see-through a-Si PV cells with low-e coatings. Applied Energy 87, 3431-3437

9. He, W., Zhang, Y.X., Sun, W., Hou, J.X., Jiang, Q.Y., Ji, J., 2011. Experimental and numerical investigation on the performance of amorphous silicon photovoltaic window in East China. Building and Environment 46, 363-369.

10. Hegazy, A.A., (2000), Comparative Study of the Performances of Four Photovoltaic/Thermal Solar Air Collectors, Energy Conversion and Management, Vol. 41, pp. 861-881.

11. KundakciKoyunbaba, B., Yilmaz, Z., Ulgen, K., (2011), An Approach for Energy Modeling of a Building Integrated Photovoltaic (BIPV) Tromb Wall System, Energy and Buildings, In Press.

12. KundakciKoyunbaba, B., Yilmaz, Z., (2012). The Comparison of Tromb Wall Systems with Single Glass, Double Glass and PV Panels, Renewable Energy, Vol. 45, pp. 111-118

13. Li, D.H.W., Lam, T.N.T., Chan, W.W.H., Mak, A.H.L., 2009. Energy and cost analysis of semi-transparent photovoltaic in office buildings. Applied Energy 86, 722-729.

14. Lu, L., Law K.M., 2013. Overall energy performance of semi-transparent single-glazed photovoltaic (PV) window for a typical office in Hong Kong. Renewable Energy 49, 250-254.

15. Miyazaki, T., Akisawa, A., Kashiwagi, T., 2005. Energy savings of office buildings by the use of semitransparent solar cells for windows. Renewable Energy 30, 281-304.

16. Ng, P.K., Mithraratne, N., 2014. Lifetime performance of semi-transparent building-integrated photovoltaic (BIPV) glazing systems in the tropics. Renewable and Sustainable Energy Reviews 31, 736-745.

17. Olivieri, L., Caamano-Martin, E., Moralejo-Vazquez, F.J., Martin-Chivelet, N., Olivieri, F.,NeilaGonzalez, F.J., 2014. Energy saving potential of semi-transparent photovoltaic elements for building integration. Energy, http://dx.doi.org/10.1016/j.energy.2014.08.054

18. Raji , M. Hasnaoui , A. Bahlaoui . Numerical study of natural convection dominated heat transfer in a ventilated cavity: Case of forced flow playing simultaneousassisting and opposing roles. International Journal of Heat and Fluid Flow 29 (2008) 1174-1181

19. S.L. Sinha, R.C. Arora,SubhransuRoy.Numerical simulation of two-dimensional room air flow with and without buoyancy. Energy and Buildings 32_2000.121-129

20. Sun, W., Ji, J., Luo, C., He, W. (2011), Performance of PV-Tromb Wall in Winter Correlated with South Façade Design, Applied Energy, Vol. 88, and Issue 1, pp. 224-231.

21. Woods L.C., A note of numerical solution of fourth differential equations, Aero. Q. 5 (1954) 176-1 84.

22. Yilmaz, Z., Kundakci, B., (2008), An Approach for Energy Conscious Renovation of Residential Buildings in Istanbul by Tromb Wall System, Building and Environment, Vol. 43, Issue 4, pp. 508-17

23. Zamora, B., Kaiser, A., (2009), Thermal and Dynamic Optimization of the Convective Flow in Tromb Wall Shaped Channels by Numerical Investigation, Heat and Mass Transfer, Vol. 45, pp. 1393-407. 